\title{
Maithili Language
}

National Cancer Institute

\section{Source}

National Cancer Institute. Maithili Language. NCI Thesaurus. Code C154017.

An Indo-Aryan language spoken in the Bihar and Jharkhand states of India. 